\title{
Risk Quotient of Airborne Paraquat Exposure among Workers in Palm Oil Plantation
}

\author{
Maksuk $^{1}$, Tan Malaka², Suheryanto ${ }^{3}$, Abu Umayah ${ }^{4}$ \\ ${ }^{1}$ Health Polytechnic, Palembang, Indonesia \\ ${ }^{2}$ Faculty of Medicine, Sriwijaya University, Indonesia \\ ${ }^{3}$ Faculty of Mathematical and Natural Science, Sriwijaya University, Indonesia \\ ${ }^{4}$ Faculty of Agriculture, Sriwijaya University, Indonesia
}

\section{Article Info}

Article history:

Received Feb 20, 2018

Revised Apr 11, 2018

Accepted Jun 30, 2018

\section{Keyword:}

Airborne paraquat

Palm oil plantation

Risk quotient

Workers

\begin{abstract}
Paraquat is the herbicide widely used at palm oil plantations, although usage it in some countries has been banned and restricted. Paraquat spraying was not appropriate procedure could be polluted the environment and lead to health disorders workers. Paraquat could enter the body through inhalation, dermal and ingestion, one of frequent routes through inhalation during spraying weeds in plantation areas. This study aimed was to analyze potential inhalation dose and Risk Quotient to workers at palm oil plantation. This research was a descriptive study with cross sectional design and analysis of environmental health risk methods. Airborne Paraquat residue was collected from 8 workers with occupational activity as a supervisor and sprayer. Airborne Paraquat residue was measured for 25 minutes during spraying by using personal air sampler at worker's breathing zone. Airborne Paraquat residue was detected by High Performance Liquid Chromatography (HPLC) with NIOSH 5003 methods. The average of airborne Paraquat residue was $0.0125 \mathrm{mg} / \mathrm{m} 3$, it values was less than the Threshold Limit Value $\left(0.05 \mathrm{mg} / \mathrm{m}^{3}\right)$ of American Conference of Government Industrial Hygienists, but the average of potential inhalation dose was $0.001 \mathrm{mg} / \mathrm{kg} / \mathrm{day}$ for worker's weight $55 \mathrm{~kg}$, it was value higher than Acceptable Operator Exposure Limit $(0.0005 \mathrm{mg} / \mathrm{kg} / \mathrm{day})$ and the calculation of Risk Quotient (RQ) was more than 1, it conditions was unacceptable for workers. Although, airborne Paraquat residue were safe, but potential inhalation dose and Risk Quotient (RQ) were unsafe for workers, cause it can be lead to lung function disorders. Therefore, for further studies it was necessary to assess the lung function of workers and the use of personal protective equipment must be completely and standard.
\end{abstract}

Copyright $\odot 2018$ Institute of Advanced Engineering and Science. All rights reserved.

\section{Corresponding Author:}

Maksuk,

Health Polytechnic, Palembang, Indonesia,

Japan Merdeka 10A Palembang, Sumatera Selatan, Indonesia.

Email: maksuk@poltekkespalembang.ac.id

\section{INTRODUCTION}

Recently, the use of pesticides were increasing in agricultural and plantation areas, particularly in developing countries including Indonesia, the number of pesticides used and listed as many as 3.207 formulations for agriculture and plantation [1]. Herbicides were widely used pesticides in agricultural and plantation areas, their use was about 50-60\% [2], and the widely used herbicides ingredient is Paraquat dichloride [3]. Paraquat (1, 1-dimethyl, 4, 4-bipyrididum) is a toxic herbicides and classified as category II hazard [4]. The uses of Paraquat have been banned in some countries, including 27 countries in Europe and in 10 countries restricted [5], while Paraquat is classified as a restricted pesticide in Indonesia [6]. 
In developing countries including Indonesia, Paraquat is used freely and easily available on the market. It condition can cause the workers exposure to Paraquat quite high mainly on sprayers and supervisors during spraying in plantation areas [7]. Paraquat exposure to workers during spraying could be through inhalation, dermal and ingestion routes [8]. Paraquat exposure could lead to death because lethality of its very high, with a mortality rate of $70-80 \%$ [9].

The average death of Paraquat poisoning were about $60-80 \%$, majority of cases were moderate to severe, deaths were generally due to hypoxia, secondary to pulmonary fibrosis [10]. In addition, the application of Paraquat spraying by farmers was related to respiratory disorders in South Korea [11]. Studies on pesticide applicators in Iowa and North Carolina, USA reported that there was association between shortness of breath and Paraquat exposure [12]. Paraquat concentrations sprayed manually could be deposited in the nose and contribute to internal dose workers [13]. The potential dose of Paraquat can be absorbed into the worker's body through inhalation, ingestion, dermal routes and accumulates in the lung, liver, heart, kidneys and other organs[9], [14].

Previous study in Malaysia reported that Paraquat air concentration measured during $25 \mathrm{~min}$ spraying at workers' breathing zone was $0.125 \mathrm{mg} / \mathrm{m}^{3}$ and potential inhalation dose calculated from air concentrations was $0.025 \mathrm{mg} / \mathrm{kg} /$ day [15]. Paraquat concentration also found in air was $0.24-0.97 \mu \mathrm{g} / \mathrm{m}^{3}$ during the measurement of 8 hours occupational exposure to Paraquat in Malaysia [16]. Therefore, it was necessary to measure airborne Paraquat residue, assessment of potential inhalation dose and Risk Quotient at palm oil plantations.

\section{RESEARCH METHOD}

This research was a descriptive study with cross sectional design and analysis of environmental health risk methods. This study was conducted on August 2016 at palm oil plantation in Banyuasin District South Sumatra Province Indonesia. Airborne Paraquat residue was collected from 8 workers with occupational activity as a supervisor and sprayer. Airborne Paraquat residue was measure for 25 minutes during spraying by using personal air sampler at worker's breathing zone. Airborne Paraquat residue was detected by High Performance Liquid Chromatography (HPLC) with NIOSH 5003 methods.

Data were collected from sprayers and supervisors and measured at worker's breathing zone using personal air sampler during spraying for 25 minutes. Before measuring, flow rate was calibrated by internal calibrator, set the flow rate to $2 \mathrm{~L} / \mathrm{min}$. Furthermore, put the personal air sampler on the workers waist and place the filter tube with distance of $30 \mathrm{~cm}$ at breathing zone and then stored samples before sending to laboratory for examination. Airborne Paraquat residue was tested in laboratory by High Performance Liquid Chromatography (HPLC) with NIOSH 5003 methods. Potential inhalation dose and Risk Quotient (RQ) were calculated by mathematical equations (1) and (2) [17].

$$
\begin{aligned}
& I=\frac{C \cdot R \cdot t_{E} \cdot f_{E} \cdot D_{t}}{W_{b} \cdot t_{a v g}} \\
& R Q=\frac{I}{R F C}
\end{aligned}
$$

The variables were used to calculate potential inhalation dose and Risk Quotient (RQ) i.e. airborne Paraquat residue $\left(\mathrm{C}: 0.0125 \mathrm{mg} / \mathrm{m}^{3}\right)$, breathing rate $\left(\mathrm{R}: 0,83 \mathrm{~m}^{3} / \mathrm{jam}\right)$, time of exposure $\left(\mathrm{t}_{\mathrm{E}}: 8 \mathrm{hours} / \mathrm{day}\right)$, frequency of exposure ( $f_{\mathrm{E}}: 250$ days/year), duration of exposure ( $\mathrm{D}_{\mathrm{t}}: 30$ years for non-carcinogenic substances), average time period (duration of exposure x 365 days) and worker's weight (minimum weight, maximum weight, average weight of workers at palm oil plantation and average weight of Indonesian workers) and Acceptable Operator Exposure Limit (AOEL:0.0005 mg/kg/day).

\section{RESULTS AND ANALYSIS}

\subsection{Airborne Paraquat Residue}

The results of airborne Paraquat residue were described in Table 1. Based on Table 1 showed that the average of airborne Paraquat residue was $0.0125 \mathrm{mg} / \mathrm{m} 3$ and that value was less than Threshold Limit Value recommended of ACGIH (American Conference of Government Industrial Hygienists) [18]. This condition was caused by Paraquat solution used with a $20 \%$ solution form and before being sprayed it 
was diluted with $100 \mathrm{ml}$ water and mixed into 15 liters of water. Consequently, when sprayed Paraquat particles were more easily fall to the ground and airborne Paraquat residue was slightly.

Table 1. The Results of Laboratory Test of Airborne Paraquat Residue Measured by Personal Air Sampler at Workers' Breathing Zone at Palm Oil Plantation $(n=8)$

\begin{tabular}{ccc}
\hline Spraying Period & $\begin{array}{c}\text { Airborne Paraquat Residue } \\
\left(\mathrm{mg} / \mathrm{m}^{3}\right)\end{array}$ & $\begin{array}{c}\text { Threshold Limit } \\
\text { Value }\left(\mathrm{mg} / \mathrm{m}^{3}\right)\end{array}$ \\
\hline During Spraying (25 min) & 0.0125 & $0.5^{*}$ \\
\hline
\end{tabular}

*ACGIH (2015)

Similar study was reported that airborne Paraquat concentrations at palm oil plantations in Malaysia was $0.125 \mathrm{mg} / \mathrm{m}^{3}$, Paraquat measured using personal air sampling at breathing zone for 25 min during spraying [15]. Airborne Paraquat residue was also found between $<0.0001-0.00024 \mathrm{mg} / \mathrm{m}^{3}$ at banana plantations in Costa Rica [19]. In addition, airborne Paraquat residue measured during spraying was found respectively $0.13 \mathrm{mg} / \mathrm{m}^{3}$ and $0.55 \mathrm{mg} / \mathrm{m}^{3}$ [20]. Total Paraquat concentrations in the air was found $0.026 \mathrm{mg} / \mathrm{m}^{3}$ at cotton plantations California [21], while at rubber and palm plantations in Malaysia each were found respectively between $0.001-0.01 \mathrm{mg} / \mathrm{m}^{3}$ and $<0.00005-0.09 \mathrm{mg} / \mathrm{m}^{3}$ ) [22].

\subsection{Potential Inhalation Dose of Paraquat Assessment}

The results of inhalation potential dose were described in Figure 1. Based on Figure 1 shows that the potential inhalation dose of paraquat exposure were between $0.0007-0.0013 \mathrm{mg} / \mathrm{kg} / \mathrm{day}$, the value more than Acceptable Operator Exposure Limit $(0.0005 \mathrm{mg} / \mathrm{kg} / \mathrm{day})$ [23]. It means this condition was unsafe for workers during Paraquat spraying at palm oil plantation for 8 hours/day.

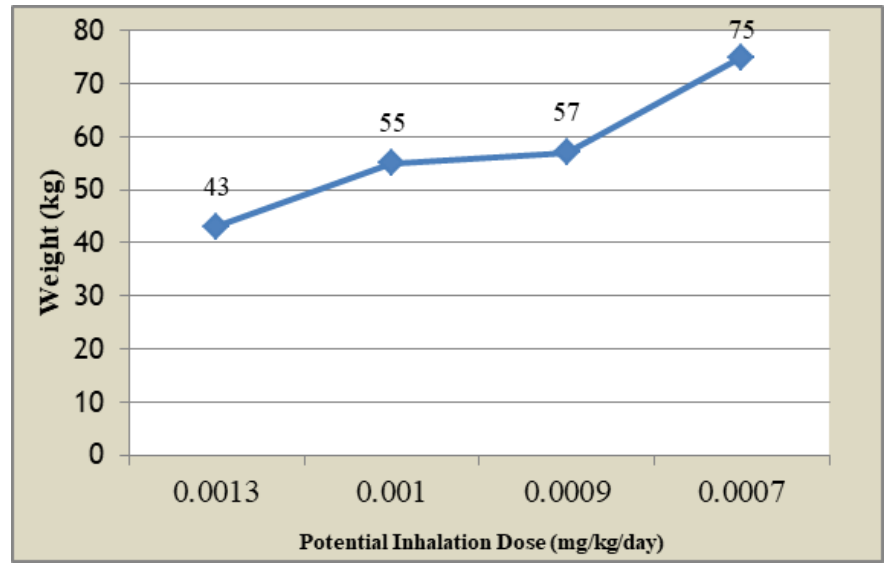

Figure 1. Potential inhalation dose of paraquat exposure

The values of potential inhalation dose at palm oil plantation was more than Acceptable Operator Exposure Limit $(0.0005 \mathrm{mg} / \mathrm{kg} / \mathrm{day})$ [23]. It means that a potential inhalation dose of Paraquat at palm oil plantations was unsafe for workers during Paraquat spraying for 8 hours/day with the frequency of exposure 250 days/year for next 30 years. According to research at plantations in Malaysia were reported that potential inhalation dose of Paraquat was $0.025 \mathrm{mg} / \mathrm{kg} /$ day (breathing rate $1.75 \mathrm{~m}^{3} / \mathrm{h}$, time of exposure 8 hours/day, weight $70 \mathrm{~kg}$ ) [15].

In addition, potential inhalation dose was found about $0.0000163 \mathrm{mg} /$ day (breathing rate of $1.7 \mathrm{~m}^{3} / \mathrm{h}$ for light working) [24]. The difference of potential inhalation dose of Paraquat was determined by measurements of airborne Paraquat residue, time of exposure, frequency of exposure, duration of exposure, duration of exposure and worker's weight [17]. In addition, the concentration of Paraquat entering the body during spraying was determined by Paraquat evaporation, Paraquat sprayed in droplet form and size of Paraquat particles have a sufficiently large size between $50-100 \mu \mathrm{m}$ so it can be entered to respiratory tract 24. However, another study reported that inhalation routes represent relevant exposure routes for internal dose exposure [19] and Paraquat was very toxic through inhalation route [24]. 
The average of potential inhalation dose was $0.0009 \mathrm{mg} / \mathrm{kg} / \mathrm{day}$, which was estimated airborne Paraquat residue at worker's breathing zone during spraying, was 1.8 times higher than the proposed Acceptable Operator Exposure Limit $(0.0005 \mathrm{mg} / \mathrm{kg} / \mathrm{day})$. It conditions can be lead to respiratory disorders for workers. Therefore, to reduce the exposure of airborne Paraquat residue to the workers during spraying, so the complete use of personal protective equipment is required for workers. In addition exposure time per day and frequency of exposure should also be reduced.

\subsection{Risk Quotient of Paraquat Exposure via Inhalation}

Risk Quotient was described in Figure 2. Based on Figure 2 showed that the value of Risk Quotient was more than 1 , it means that condition was unacceptable for workers during spraying Paraquat at oil palm plantations working for 8 hours/day with frequency of exposure 250 days/year for duration of exposure for the next 30 years. This condition was also unsafe for respiratory health workers. Therefore, it is necessary to risk control management by reducing the concentration of Paraquat in the air, time of exposure, duration of exposure and frequency of exposure.

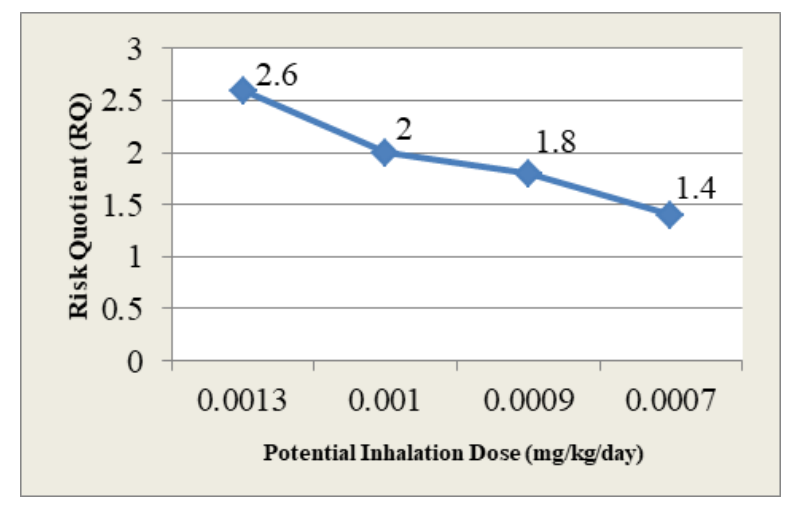

Figure 2. Risk quotient of paraquat inhalation dose at palm oil plantation

Although according to ACGIH that maximum of airborne Paraquat residue was $0.05 \mathrm{mg} / \mathrm{m}^{3}$, but the results of risk control management was reduced maximum of airborne Paraquat residue was only 0.006 $\mathrm{mg} / \mathrm{m} 3$. Furthermore, the workers may be exposed to Paraquat with time of exposure for 125.3 days per year and frequency of exposure was about 4 hours/day, and the duration of exposure was only the next 15 years. It conditions accordance with WHO recommendations that workers who apply for pesticide spraying may be allowed for 4-5 hours/day [25]. In addition, the guidelines for the use of pesticides in Indonesia also recommended that workers conducting spraying should only be exposed to 5 hours/day [26].

\section{CONCLUSION}

The study provides important information on airborne Paraquat residue during spraying, potential inhalation dose, Risk Quotient and how to risk control management. Despite the results of Paraquat concentration measurements in the air was less than Threshold Limit Value, but potential inhalation dose of Paraquat more than Acceptable Operator Exposure Limit and Risk Quotient was unacceptable for workers during Paraquat spraying at oil palm plantations. Therefore, it was necessary to risk control management by determining the safe boundary value for airborne Paraquat concentration, exposure time, exposure frequency and duration of exposure.

Recommendations for the workers that workers must be used the personal protective equipment completely and standard during paraquat spraying; for company must be provided the personal protective equipment completely and give punishment to the workers who did not use it; for further studies, it necessary to assess the lung function of workers to early detect pulmonary fibrosis.

\section{ACKNOWLEDGEMENTS}

The author would like to thank to Indonesia Endowment Fund for Education, Environmental Science Program of Sriwijaya University, Company of Palm Oil Plantation in Banyuasin District and Government of South Sumatera Province. 


\section{REFERENCES}

[1] Ministry of Agriculture RI Directorate General of Agricultural Infrastructure and Production, "Pesticides Agriculture and Forestry Registered”, 2016.

[2] Qiao F., "pesticide use and farmers health in China's rice production", China Agricultural Economic Review 2012, 4(4): 468-484. DOI 10.1108/17561371211284821, 2012.

[3] Soenardjo, "Isolation and characterization of coral bacterial degradation of paraquat herbicide compounds in Teluk Awur Beach of Jepara", Thesis, Diponegoro University, Semarang, 2004.

[4] World Health Organization, "The WHO Recommended Classification of Pesticides by Hazard and Guidelines to classification", Geneva 2009, http://www.jitimes.com.fj/story.aspx?id=141776 (accessed 6 March 2015).

[5] Watts M. Paraquat, "PANAP (Pesticide Action Network Asia \& Pacific)", 2011.

[6] Minister of Agriculture Regulation RI, "List of Pesticides Active Ingredients in Banned and Restricted”, 2007.

[7] Djojosumarto, “Agricultural Pesticide Application Technique”, Yogyakarta: Kanisius, 2008.

[8] Centre of Disease Control, Fact about Paraquat, 2003.

[9] Banday TH, Bashir S, Bhat Shasikant, et al., "Manifestation and management of paraquat intoxication a deadly poison", IOSDR, Journal of Dental and Medical Sciences 2014, 12(6): 74 - 76.

[10] Dinis-Oliveira RJ, Duarte J.A., "Paraquat poisonings: mechanisms of lung toxicity, clinical features and treatment", Critical Review Toxicologyogy 2008, 38:13-71, 2008.

[11] Cha ES, Lee YK, Moon EK, et al., "Paraquat application and respiratory health effects among south korean farmers", Occup Environ Med 2012. 69(6):398-403, doi: 10.1136/oemed-2011-100244, 2012.

[12] Hoppin JA, Umbach DM, London SJ, et al., "Chemical predictors of wheeze among farmer pesticide applicators in the Agricultural Health Study. Am J Respir Crit Care Med 2002, 165(5):683-689, 2002.

[13] Wesseling C, Hogstedt C, Picado A, Johansson L., "Unintentional fatal paraquat poisonings among agricultural workers in Costa Rica: report of 15 cases", Am J Ind Med 1997, 32(5):433-41, 1997.

[14] Sexton K, Needham LL, Pirkle JL., "Human biomonitoring of environmental chemicals, measuring chemicals in human tissues is the "gold standard" for assessing people's exposure to pollution", American Scientist 2004, 92:3845, 2004.

[15] Morshed MM, Omar D, Mohammad R, Wahed S \& Rahman MA., "Airborne Paraquat Measurement and Its Exposure in Treated Field Environment", International Journal of Agriculture \& Biology 2010, 12: 679-684, 2010.

[16] Chester G, Gurunathan G, Jones N, Woolen BH., "Occupational exposure of Sri Lankan Tea Plantation Workers to Paraquat”, Bulletin WHO 1993, 71:625-632, 1993.

[17] Louvar JF, Louvar BD., "Health and Environmental Risk Analysis: Fundamentals with Application", New Jersey: Prentice Hall, 1998.

[18] Lock EA, Wilks M.F., "Paraquat. In: Handbook of pesticide toxicology", 2nd Ed, San Diego, Academic Press, 2001.

[19] American Conference of Government Industrial Hygienists (ACGIH), TLV and BEIs Based on The Document of The Threshold Limit Values for Chemical Substances and Phisical Agent \& Biological Exposures Indices, 2015.

[20] Van Wendel De Joode BN, De Graaf Inge AN, Wesseling C, Kromhout H., "Paraquat exposure of knapsack spray operators on banana plantations in Costa Rica", International Journal Occupational Environmental Health, 2(4):294-304, 1996.

[21] Chester G, Ward R.J., "Occupational Exposure and Drift Hazard during Aerial Application of Paraquat to Cotton", Arch Environmental Contamination Toxicology, 13:551-563, 1984.

[22] Makovskii V.N., "Toxicological and Hygiene Studies of Bipyridylium Herbicides Diquat and Paraquat", PhD Thesis, Vinnize, 1995.

[23] European Commission (EC), "Review report for the active substance paraquat", Health \& Consumer Protection Directorate General, Brussels, 2003. http://ec.europa.eu/food/plant/protection/evaluation/existactive/list_paraquat.pdf.

[24] Seiber JN and Woodrow JE., "Airborne Residues and Human Exposure", In: Siewierski M. (ed.), "Determination and Assessment of Pesticide Exposure 1984, 133-146. Studies in Environmental Science 24, Elsevier, New York.

[25] US EPA, 1997. Facts Paraquat dichloride http://www.epa.gov/pesticides/reregistration/status_page_p.htm

[26] Ministry of Agriculture RI Directorate of Agricultural Facilities and Infrastructure, Guidelines of Using Pesticides at Agriculture, 2011. 